\title{
Anthropological condiments for a theater scene myth and rite in intercultural representation
}

\begin{abstract}
For this research we collected contemporary versions of the Mapuche "Kai KaiTreng Treng" myth, with the aim of writing a theater script of the myth. Data were collected using ethnographic methods and focus on the interdisciplinary contribution of anthropology and theater to the cultural process of indigenous people and to the input that these disciplines can make in this way, considering the ethic responsibilities that underlie the process of intercultural representation. The cultural elements -myths and ritual-that were taken into consideration during data collecting and writing of the theater scrip are described and analyzed from an anthropological perspective.
\end{abstract}

Keywords: ethnography, mapuche, interculturality, theatrical script
Volume 3 Issue 2 - 2018

Claudio Espinoza-Araya

Associate Researcher, Center for Intercultural and Indigenous Studies (CIIR), Mexico

Correspondence: Claudio Espinoza-Araya, Associate Researcher, Center for Intercultural and Indigenous Studies (CIIR), Mexico, Email cespinoza@academia.cl

Received: June 22, 2017 | Published: March 21, 2018

\section{Introduction}

The social sciences and art have more common coincidences and attributes than meets the eye. Freeing ourselves from a certain rigidity and exclusion rooted in some methodological approaches we can see that both anthropology and theater turn their eyes towards a common goal. Both disciplines point to an analogous object-subject. Whether it is a deep inquiry or a casual approach, it becomes inevitable to approach a mysterious and at once fascinating universe: the unveiling of staged humanity, human behavior as a whole. From a Greek tragedy represented two thousand years ago or the tale of an Amazonian tribe trying to accommodate the swift 21 st century, these experiences draw us a brushstroke of a humanity that thinks unique and diverse at the same time.

It is not the only coincidence. There are more and this is reflected in some paradigmatic encounters that have occurred between both disciplines. ${ }^{1-3}$ Much would help us to search for it, perhaps we can enrich the knowledge that exists around the human experience or, more modestly, add new images of what we are as humans. The present text attempts to contribute to this. We will describe an anthropological research that aimed to collect contemporary accounts of the Kai Kai-Treng Treng Mapuche myth and then elaborate an intercultural script that would allow its staging. The idea was to resort to an epistemology and support that, combining anthropological and theatrical aspects, would allow access to intercultural knowledge and facilitate its diffusion. It was an experience that was conducted through the ethnographic method, passing through Mapuche poetics and epistemology, which crossed the ethnological reflection and became theatrical script. Although the initial question and the final result were thought from the theatrical, the road was doubly anthropological, since on the one hand He turned to ethnography, an anthropological method par excellence and, on the other hand, he assumed an anthropological perspective in the sense of examining the different social and cultural realities from an intercultural perspective, seeking to transcend a unilaterally Western view and, above all, discarding prejudices Which identify the cultures of indigenous peoples as retrograde, anchored in the past and who refuse to enter modernity. On the contrary, we started by assuming cultural diversity and saw an enriching value in it. Thus we find that the mythical stories of the Mapuche people are, as in all human societies, stories that try to explain a certain reality and that, therefore, expose a worldview.
Next, we present the methodological approach of the investigation, to then give way to the anthropological treatment with respect to the myths, establishing its archetypal character and also highlighting the particularities of the Mapuche story through a summarized and systematized version. We then analyze this relationship paying attention to the intercultural complexities involved and the ethical and political responsibility involved in its staging. At the end, we perform a review of the central axes of the theatrical script, those based on central cultural aspects of the history and present of the Mapuche people, specifically the central character of ritual congregation and shamanic action.

\section{Methodological approach}

The research was conducted through the ethnographic method. In general, we can say that ethnography is one of several types of social research methods. It is usually characterized as a type of approach that seeks an understanding from the perspective of the people studied, an issue that can be achieved by direct observation of daily activities, which involves the participation of the observer in the particular contexts where such activities. ${ }^{4,5}$ This participation takes place during a relatively long period in which one observes, listens and, in the end, learns from the other's gaze, thus obtaining a set of data That allow to understand the facts and processes that have been identified as relevant for the investigation. In this way "the ethnographer or ethnographer participates in the daily life of people for a relatively long time, seeing what happens, listening to what is said, asking questions, that is, collecting all kinds of data accessible to shed light On the subjects he or she has chosen to study. ${ }^{6}$

This entire itinerary is known as an ethnographic process. ${ }^{4}$ subsequently this information is systematized, analyzed and complemented with ethnological theory, which in turn allows the elaboration of interpretative texts on different human societies and cultures. In anthropology, the most common form that this ethnographic product acquires is the monograph, although there are also other forms, such as documentary film and, in our case, a script and play. The research described here assumed the ethnographic method as its own, for which two months of research were available in different parts of the Mapuche territory, both on the Chilean and Argentine sides. We sought to compile current versions of the myth, trying also to learn the Mapudungun, the Mapuche language and 
observe the daily practices in order to know the different scenarios where the transmission of the myth occurs.

Various qualitative techniques were used, including participant observation, open and semi-structured interviews. During the fieldwork, the first discussions about the conceptual framework that should guide the structure of the theatrical guideline were immediately carried out. Evidently this work was concluded once the field research was completed and it was the competition of the theater director who was part of the team. However the data obtained in the field served as the basic platform for such work. These anthropological aspects that allowed the construction of the script are those that are approached in this article.

\section{Culture and myth}

In 1871 the British anthropologist EB Tylor ${ }^{7}$ delivered what can be considered the first anthropological definition about the concept of culture. This author defined culture as "that complex whole which includes knowledge, beliefs, art, morals, law, customs and any other habits and capacities acquired by man living in society".? Although the later anthropological work was partly responsible for criticizing, expanding or specifying this definition, ${ }^{8}$ the interesting thing is that it establishes certain key premises to approach the notion of culture, fundamentally its inherent condition to human existence. The culture thus understood turns out to be a demarcation line that critically distinguishes the human being from the other species as evidencing the presence of an ordering of the environment based on own representations. Whether expressed in a kinship system, food preparation or myth-making, culture always involves choosing a regulated order and choosing an order, whatever it may be, involves the rejection of other possible orders. ${ }^{9}$

Culture orders a wide world in possibilities, regulates it and this ordering is arbitrary and therefore shown to be extremely diverse. This conception implies an absolute rejection of the nineteenth-century racist reminiscences,${ }^{10}$ in that it is not necessary to introduce any genetic variation so that any human being can learn and develop the intellectual, creative, affective or other capacities of Any human group, since the repertoire of the symbolic expressions are all already in their brain and, therefore, there is a humanity united by mental instruments, but that distinguishes itself by the molding that the cultural factors of these instruments do. This arbitrary selection of symbolic expressions allows the individual to identify the true of the false, the good of the bad, the sacred of the profane and the human of the nonhuman. The symbolic is imposed in nature, for example, through the toponymy that names the territory or the natural process that involves food what to eat, how, when. Thus, all symbolic manifestation is social and all human activity tends toward the symbolic. ${ }^{11}$

Under this realization, myths constitute a way of ordering and interpreting the world. They are stories present in all human societies that legitimize and explain the basic principles that constitute the belief systems on which a particular society is built. They come to be an expression of the ideological framework on which the social corpus of a society stands. ${ }^{12}$ In this sense, it is necessary to emphasize that the mythical capacity, as well as the recurrence to these cultural constructions, is present in the whole species. Every society, in one way or another, has been molded and resorted to a greater or lesser degree to its mythical creations. For Levi-Strauss ${ }^{13}$ each mythology reflects one of the realizations of the virtually infinite combinatorial of a small number of mental structures. The principle of structural analysis lies in these constant comings and goings between these mental structures, their various narrative realizations and their geographical context that is, the natural and social environment which myths are meant to represent. Its exercise is possible thanks to the fact that such structures exist in the minds of each and every human being.

\section{About myths}

The myths present certain universal characteristics; hence one speaks of mythical archetypes. ${ }^{14}$ There is a consensus in pointing to myths as founding accounts that, from the earliest times, are transmitted from generation to generation by the members of a certain society. For a story to acquire the status of myth, two basic conditions must be given: first, that the elements of the myth enter into a semantic and formal compatibility relationship with the set of myths of the society that sustains it and second, that the myth from being a local story to becoming a general, exemplary, paradigmatic history. In this way, myths are always and everywhere presented as accounts that express the work of human thought to systematically organize the universe. ${ }^{12}$ Time occupies a fundamental place in the generation of myths, either referring to a mythical time or to the antiquity of the origin of the myth, which implies assuming eventual changes in the living conditions of a society and, therefore, that society It must readjust its mythical creations to the new material and ideational contexts. Thus, the myth oscillates between processes that can lead to their death or processes of transformation and adaptation to the new social climate, thus allowing their survival.

The presence of the time factor materializes in two ways, both as instruments that allow turning reality into metaphor. The first is expressed in an explicit language. Most of the myths begin their tale by alluding to a time 'other', pointing out such issues as 'at the beginning of time' or 'long ago', 'in illo tempore', which implies, at first, a detachment of The immediate reality to lead us to a different temporal moment that goes away and differs from the present conditions. The second is related to the elements that make up the mythical plot. The myth projects on a same plane instances belongs to differentiated levels of the universe, for example placing in a same temporality and spatiality to personages coming from the animal kingdom, natural and human, falling most of the times in a total contradiction with the laws of the nature. The mythical account therefore does not seek a reliable description of the real, if not rather justify the chosen order to represent that reality. This adaptation of reality to the mythical narrative has a clear social function: to gather around the same order of the universe the members of a certain society. It is a desire for consensus that is expressed in the rite, an instance in which men and women participate in the same transcendental vision that reminds them of their union as a group. ${ }^{15}$

\section{The myth itself}

The stories of the Kai Kai-Treng Treng myth are abundant. There are first the oral versions and then the written ones. The writings are found from the earliest colonial chronicles to the current systematizations carried out by some contemporary scholars. ${ }^{16-18}$ Morality, for its part, occupies a central place in the development of Mapuche culture. This people, like others, privileged the development of morality and its devices as an instrument of cultural transmission. Therefore, our research was focused on the search for contemporary oral stories of the myth, as it was interesting to find expressions 
and live interpretations of the myth. We did not look for a supposed genuine version, but rather interpretations that showed the meaning that the myth has for Mapuche communities today. Once we collected enough information we were able to distinguish some elements that place the mythical Mapuche story within a certain archetypal horizon, but we were also fortunate to appreciate how these and other elements express a certain cultural particularity. The articulation of both sources provided us with the material to imagine a theatrical script. As it is characteristic of a myth that prevails of such, the versions that we could collect show a series of common features that we systematize and we summarize in the following story: A long time ago a tragedy happened. The men forgot some important questions: they abandoned communication, either with the divinity, with nature and also between them. This abandonment, had forgotten some basic premises of how the creative spirit had devised and ordered the world, brought with it an imbalance of that order. The energies were unleashed bringing with it the chaos. It all started when Kai Kai, a serpent who rules the waters and who, annoyed that men were not complying with the precepts set in the early days, decided to end them by heavy rain and overflowing the sea. Humanity, terrified, tried to save itself, by resorting to another serpent, Treng Treng, who inhabits certain hills. Men and women went up to the hills to save themselves. Many failed to rise and died, some became fish and some became stones. Others climbed the wrong hills and also died. Only those who went up to the real Treng Treng and prayed were saved. Treng Treng, floating in the rising water, rose to the sky, very close to the sun and then the humans there were saved from drowning. Above, these had to make clay chalk to protect them from the sun and not burned to death.

Kai Kai, unable to overcome the strength of Treng Treng, undertook the retreat. The order was reestablished and, from that moment, the group of people that managed to be saved was responsible of populating the earth. This is how the Mapuche people were born. The first task to be performed after the data collection was the elaboration of a conceptual matrix of the myth, in order to provide a conceptual density to the script. The idea was that each word and every action were the expression of the structural elements of the mythical story. For this, both the archetype and the Mapuche peculiarities of the myth were deciphered. In the background, we appealed to a universal structure, but seeking to highlight an expressive particularity: the Mapuche colored. The identification of these elements was decisive for the elaboration of the theatrical script.

\section{The transmission scenario}

The myth, unlike other stories and stories, must be transmitted in a particular context. It is not counted anywhere, nor at any time nor in any language. Everything related to the myth is regulated under precise rules. In some societies not complying with these norms implies receiving strong sanctions, either by the peers themselves or by the gods. ${ }^{13}$ In general, the myths are told by the elders of the community and, as an example, have children as their primary audience. In our case, all the interviewees said that the story was transmitted to them when they were children by their grandparents and always at the end of the day, gathered around the fire. As our interviewees turned out to be mostly adults and elders, the version that was related to them was almost always done in the Mapuche language. It was a time when there were more vernacular speakers; however, now that the linguistic context is different, the native language remains fundamental to the ritual setting. Thus, for example, in order to access the sacred sites of the territory, one has to petition respectfully in the language that god-nagech understands, the language of the Mapuches. This type of data allows us to distinguish a first anchor of the Mapuche myth with its peers of the world. The transmission of the myth is certainly regulated. On the other hand and paying attention to the Mapuche colored of the mythical archetype, we were able to perceive some aspects that reveal to us central milestones of this culture. For example, the preferential place of mythical transmission is the fire, a particularly important space within the Mapuche daily life. According to some guidelines of mapuche epistemology, ${ }^{19}$ there are certain places suitable for communication. At the community level this place is the Nguillatuhue, place of the Nguillatún, sacred mapuche ceremony, in which the best conditions are established to establish the three levels of communication: with the sacred, with nature and with human beings. At the domestic level the place par excellence for interpersonal communication is the stove. There the family meets and communication flows. We understood, then, that while containing archetypal elements, the particularities of the Mapuche myth allowed us to enter into a vast universe of knowledge with significant significant units. The temporality of the myth

The myths are founding stories that refer to a different temporal space. Although not all myths address social genesis, they are equally foundational in the sense of establishing ideological bases on a variety of topics. The myth Kai Kai-Treng Treng possesses double this character. It is, on the one hand, an account that narrates the rise of the Mapuche people and, on the other, it exposes some of the constitutive forces of the mapuche symbolic universe. In expressing cosmogonic clues, the Kai Kai-Treng Treng story allows us to understand some fundamental premises of the Mapuche worldview, for example, the importance of communication and how it relates metaphorically to the universal order. In the same sense, the fact of transforming, through the myth, the reality in metaphor allows to understand the orders trastocados and with this to confirm the communicating vessels existing between the mythical creation and the theatrical creation. If myth, when metaphorizing reality, expresses a particular order, theater can allow another kind of representation of the same order. In both the mythical narrative and its ritual representation there is an act that allows humanity to redeem its profane actions, its temporal futility, to grant it a universal transcendence by allowing access to sacred time, an eternal time. The rite that reminds us of mythical time allows us to participate in a transcendent reality. The staging of the myth Kai Kai Treng Treng, may somehow, in the manner of the rite, contribute to such a perception.

\section{Universality of the mythical story}

For a myth to be such it must abandon its individual origin and become general and paradigmatic history. According to the testimonies collected, Kai Kai-Treng Treng fully complies with such a premise. Many interviewees pointed out that the mythical snakes were not only in Mapuche territory, but all over the world. If other people had known how to pray, natural disasters could have been avoided. Thus, a story that is born in a local context, acquires universal connotation, which in turn does not prevent local interpretations of it. That is, the Universalist narrative is filled with a local sense. This fact is perhaps one of the most interesting findings of the investigation: to find live accounts of the myth so that the script allows a direct representation for the eventual spectators. And so it happened. When we were interviewing some informant and asking about the history of 
the myth, his response always referred to a general story, but colored with a local tint. Many of interviewees stated, by pointing the finger at the hill Treng Treng, showing us the palpable evidence, the precise place where the story occurred. Others told us that in the Treng Treng of their community you can see the people who became stone when the tragedy occurred. In the distance we observed a pile of rocks that ascended towards the top. Other stories referred to more recent and particular events such as the tsunami in 1960 and the way Treng Treng saved them from drowning. We find that the global, who unites a great territory, acquires meaning in its more local expressions (Long). Thus, in the script we try to reconcile the sum of local versions and interpretations found, for example, for the mapuches of the coast, Kai Kai unfolds in the marine overflow, while for the interior the expression assumes intense rain form. For this type of cases, the script tried to include both variants. ${ }^{20}$

\section{Ethical and political responsibility}

Every story contains a point of view. Words are not innocuous; they express different 'truths'. Some of these truths manage to impose themselves as 'the truth' and others are marginalized, hidden and forgotten. The stories of the indigenous peoples have wandered in the last few directions. Most of the time they have been ignored and if not, straight forwardly silenced. Other stories, other 'truths' have been imposed upon them. Some impositions are subtle and others are truly rude; some casual and some straight perverse. Thus, moving the descriptive paths of cultural diversity carries considerable responsibility. Narrating a story involves taking charge of the point of view from which it is intended to tell such a story. It is not an easy task, but this should not be an obstacle to try. Through the ethnographic method we were able to obtain a contemporary intercultural view about myth. Obviously, this Mapuche point of view is not homogeneous; indeed, we note an important diversity of approaches. Neither is there a pure, genuinely Mapuche point of view. The different societies and cultures were formed in the contact, so it is mixed looks, syncretic. ${ }^{21}$ Thus, for example, there are versions of the myth that intertwine with the versions of the diluvian myth. There are others that, perhaps naively, may contain elements that lead to dangerous interpretations and therefore should be treated carefully. We set out to collect versions of the myth that keep the faithfulness to their narrators, while trying to avoid some biases that eventually imply interpretations detrimental to the Mapuche people and culture. We are not sure we have. Surely there will be many who do not agree with our theatrical synthesis, but we believe that by explaining the arguments that brought us to it we can understand our apprehensions. Here are two examples of this discussed. Good and evil.

\section{Biblical influence}

Many versions of the myth showed a clear influence of mythical Judeo-Christian accounts. For example, some Mapuches told us about the existence of a great flood "where it rained for 40 days and 40 nights. Noah made an ark, saved himself and his family and also the Mapuches who climbed the Treng Treng." Others spoke of Kai Kai as a snake representing evil and of Treng Treng as a representative of the good. Although one of the common features of the founding myths is the figure of the flood and therefore it enters the mythical archetype, we decided not to speak of deluge in the script because the concept has a religious charge, which according to many interviewees makes the new generations of Mapuches are moving away from their own beliefs. We think therefore that despite the archetypal relationship it was better to leave the most pristine self-image of the Mapuche myth, an original story that narrates a certain cosmogonic aspect of the people. In the same sense, we decided to clear the versions that involved logic of good and evil. It is known that the first Spanish chronicles described the myth under this understanding. At present, when a whole Mapuche self-reflection about its religion and its epistemology has arisen, we can learn more about such matters. We perceive that more than forces that respond to good and evil, Kai Kai and Treng Treng are now interpreted as energies of nature unleashed by an imbalance. We decided to narrate in these terms and not in others. Now, we must reiterate that this is not a genuine version, because that perhaps did not exist or exist anywhere. Therefore, transcending an essentialist view, we prefer to adopt a contemporary version that would make sense of the current Mapuches.

\section{Avoid any racist hint}

The myth says that when Treng Treng floats in the water and rises until approaching the sun, the Mapuches had to make jars of clay to avoid burning. Some versions indicated that in that process the mapuches, resisting the force of the sun, would have remained brown. While in principle such a version should not hold any risk, reading between lines we think that can eventually lead to a racist interpretation. One might think that the Mapuches, when breaking a certain equilibrium, by failing to rule, unleashed a chaos in nature and had to resort to Treng Treng to be saved, in which, because of the proximity of the sun, his skin became dark, All of which could be considered a punishment. In this sense one could read the 'morenidad' of the mapuches as an effect of a tragedy and not as a biological process that should not imply any type of adjacent assessment.

\section{Construction of the script}

Thinking that language, as a symbolic system, is the maximum expression of culture, we decided to devise the first theatrical script in Mapudungun and then make a translation into Spanish. With the vital help of Mapuche poet César Ancalaf, every word included in the script was thought and discussed in order to know exactly its semantic reach. This operation worked as follows: First we thought of the myth, then an idea of theatrical representation, later it was translated into words and actions that had relevance to the Mapuche culture and that could represent that theatrical idea. That was how the script was thought and written. Let us take as an example some central axes of the same.

\section{The beginning}

The work begins with a presentation in Mapudungun and then translated, containing some relevant aspects of the conceptual work on the narrative to theatrical: "Kom eymun pichikeche, wechekeche, vüchakeche, ülchake domo, kom eymûn nyaimün kiñe küme llowpan fachantü chi. Vewla inafül kuxalwe mew, wiño kintüaiñ taiñ rüpalchi dungu, taiñ kuivike nüxam taiñ pu kuifike che niepeyüm chum ñi adumkapeyüm. Kuifyem, rüf kuifiem, kiñekeche che küme nüxamkakelafuingün ina küxalwe meu, nguillatukelafuingün, fey mu, kidü ñi adman mew rupay kiñe afkandungu; Chongfüy ñi küxalwe, ka ñi piwke, fey mew rupay tufachi dungü". "All of you, children, old people, young women, are welcome on this day. Now, around the hearth we will return, among all, to our ancient conversations. Our ancestors, our elders, left us a way of doing things, as a form of 
learning and also in an entertaining way. Long ago people stopped communicating. They did not communicate around the fire, Nguillatun did not, so, for what they stopped doing, there was a tragedy. The fire was gone and their hearts too. That is why what I am going to tell you now happened. "The welcome distinguishes the differences of age and gender of the public, does not encompass it under the concept of spectators, but it particularizes it, something especially characteristic of the public discourse mapuche. Then reference is made to the show that will be presented. It is pointed out that "now, around the hearth we will return, among all, our old conversations," a phrase that contains four points that fully express the effort to articulate the anthropological contribution to theatrical creation, the particular version of the myth and the cultural imprint Mapuche.

As a first aspect, the presence of the fireplace is highlighted, around which stories are told and the Mapuche culture is reproduced. This fact, on the one hand theoretical and on the other empirical, is reappropriated and converted into a theatrical input. Thus, based on the realization of a cultural fact involved in a mythical story, a scenario can be designed capable of transporting the viewer to a different reality. The theater, in this way, contributes to the knowledge of other worlds, the approach to other realities. Secondly, the phrase "we will all be backing together", corresponds to an element introduced by the work team and that pursues some well defined objectives. On the one hand and as part of the purposes of the theatrical project and the approach to the teaching of some elements of the language and the Mapuche culture, the play was intended mainly for children. The goal was to involve the children in the process of knowledge. Education, from this perspective, is understood as a joint action, where the child is the protagonist of his own learning. It seeks to put the spectators in a learning situation through a trip related by an actor, following a Mapuche cultural expression: oral history as a transmission resource. Likewise, it seeks to revalue the Mapuche culture, pretending to hold the children responsible for their own cultural heritage. Although they are important agents, it is not only the State and the school, but it also involves children living in communities, who can turn to grandparents for this type of story. Thirdly, in pointing to the fact of "returning to our old conversations", we stand before a central aspect in terms of understanding the mythic structure and from there to return the theatrical account. We have already pointed out that a fundamental characteristic of the myth is to refer to another time. So from the outset the public is ready to travel to a different time dimension.

Finally, alluding to our ancestors, we emphasize an empirical characteristic of the transmission of the story, but we also claim the value that is attributed, in terms of wisdom, to the elders in the Mapuche culture. Thus, from the beginning, the story articulates central elements of the myth and Mapuche culture: a certain space, the time factor, morality as an element of transmission and the figure of the grandfather or elder sage. It also introduces the story of a theatrical myth as an adjunct to learning and cultural claim. As we advance in the presentation, the central nucleus of the story is announced: "People long ago stopped communicating, that is, something was lost and with it the story was unleashed."

\section{Development}

The narrator points out that throughout the Mapuche territory there are Treng Treng hills, "remembered and venerated because there the ancestors were saved". Grandparents tell this story to young people so they do not make the same mistakes. In this part of the story, we highlight the empirical data. Regardless of their age, the people of the indigenous communities know and know the Treng Treng hills. Myth and memory are alive. On the other hand, we emphasize the intention of transferring the myth generationally, from grandparents to infants, alluding to two complementary purposes: remembering group membership and regulating the behavior of new generations.

Subsequently, the narrator recalls that in those times, "in illo tempore", people changed their way of life, alluding to the traumatic break between humanity and divinity, the archetypal transgression where human beings stop doing the right thing, generating The imbalance of the energies. In other myths, before human error, the gods are enraged; we, however, choose to speak of imbalance. Although many stories place Kai Kai as an evil force, contemporary de-colonial Mapuche philosophical and poetic reflection ${ }^{19}$ attempts to distance himself from the ethics of good and evil, rather referring to imbalances that can lead to disorder, chaos and Catastrophes. Moreover, some accounts speak of the influence of Kai Kai as not necessarily negative, on the contrary, because it reminds men of the fact that they have failed the norm, reminds them of their duties. In any case and archetypically, we highlight the fact of breaking the norm. As is known, ${ }^{14}$ in the founding myths there are several moments. The first corresponds to a harmonious coexistence between men and gods, in the second; this coexistence is broken by a lack of humans. At a third moment the gods are enraged - or the energies are unbalanced, which leads to a fourth moment where humans return to the rite, recompose the fault, giving way to a restoration of order, last moment. The script addresses the normative break with contemporary examples emerging from field work. Thus, for example, we address the loss of communication in the three senses of Mapuche epistemology: communication between peers, communication with nature and communication with the divine. Faced with this situation, Ngenemapún, the creative spirit of the universe, decides to call to order, restore lost order, action that takes us to the core of the plot.

\section{Climax}

The actors, characterized as snakes, realize the confrontation between unleashed energies: Kai Kai trying to exterminate humanity and Treng Treng to save her. The script tries to collect the different versions regarding the consequences of this fight, for example, the transformation into fish or stones of those who could not be saved. Then the story of the myth continues exposing other situations of the struggle between the snakes and the adventures of humans trying to protect their lives. Later on, the climax of the story is reached, to the anthropological and theatrical synthesis of what it is intended to represent: the ritual congregation and shamanic tradition of the Mapuche people. As noted, myths do not seek to recreate a reliable description of the real, but rather justify a chosen order that represents that reality. The transmission of the mythical narrative, meanwhile, has a clear social function, which is to gather around that chosen order the members of a given society. The device that expresses and recalls this desire for consensus and group unity is the rite, a particularly important aspect in the Mapuche culture. ${ }^{21}$

As we have always had the objective of giving conceptual and intercultural consistency to the script, the fact that we encounter the 
palpable force of the relevance of the rite for contemporary Mapuche society ${ }^{17}$ led us to construct the end of the script around this Central aspect of the Mapuche culture. The actors represent people asking Treng Treng to protect them. He observes them in their attempts to save themselves and thinks that it is not good for humanity to be extinguished. Then he shouts out. The final fight between the two is unleashed Snakes However, the battle is only defined when a woman, the shamanic figure par excellence of Mapuche society, called machi, takes a kultrún ceremonial tone and begins to shake it imitating the sound of Treng Treng. He wants to give you encouragement; he wants to beg you to save them. A group begins to accompany it. People start screaming ya, ya, ya, ya, ya. Suddenly a prayer begins, many prayers directed by this woman. The prayer signals the humility of the human being in the face of nature, the creative spirit. With him it is emphasized that humanity will now return to its path, which will respect existence, which will continue to beg. The battle is defined in favor of Treng Treng. The narrator ends by pointing out that those who were saved were responsible for re-populating the land. And so, thanks to the ritual congregation, the Mapuche people are born.

\section{Conclusion}

Immersed in the challenges of representation and even more so, intercultural representation and recreation, this article attempted to expose a real and concrete approach to this challenge. It was not easy, on the contrary, he demanded that the research team, composed of an actor, a Mapuche poet and an anthropologist, put at the service of interdisciplinary the maximum potential of each of his professional trajectories. In this sense, the article, which is basically an anthropologist's reflection on his participation in a major theatrical project, sought to provide elements for the joint work between two disciplines in different appearance, but with more common issues than Tends to think.

To begin with, we sought to situate the mythical creations of indigenous peoples, in this case Mapuche, as an expression of the immense creative capacity shown by humanity throughout its history. No more any less. The Mapuche people like all the other peoples of the world, constructed stories to explain and order their surroundings. These creations are not; therefore, superstitions of peoples that were anchored in the past, but concrete products in the long historical adaptation of the human being to his conditions of life. And precisely because they are historical, they do not exist in a genuine way, but adapt to the changing conditions of human evolution. In this way, the project, as well as this article that describes it, seeks to remember the historicity of the peoples, placing them in history, neither despising nor idealizing them through the essentialization of their culture.

That is why we worked with live accounts of the myth, with versions related by current mapuches, with the aim of representing them trying to consider two aspects that we believe are fundamental for the purposes of intercultural representation pursued by research, i.e, on the one hand Coherence with the cultural context of the people with whom they worked. That is to say, the staging of the mythical story was made considering these precautions and anthropological recommendations to allow a recreation, a sample of a human set that is thought similar and different at the same time and on the other hand, safeguarding in practice the notion Which analogous the performance element of the rite and the theater. At that stage, we discovered that this attempt entailed other challenges, for example, that of the ethical and political responsibilities aligned with the very fact of relating otherness. As we have pointed out, words are not innocuous, they contain dissimilar germs that can express different sensitivities and some that may benefit peoples, but can also affect them strongly. We could not reproduce stories that deny or make invisible to certain social actors, but we try to recreate collecting the vernacular version of the phenomena that we were interested in as faithfully as possible. This is a difficult task, but we made the attempt with the greatest rigor and commitment possible. In parallel, we note the closeness that theatrical representation has with other analogous expressions of the peoples of the world, for example, their rites. If a mythical transmission of the Mapuche communities of today reproduces a ritual scenario reminiscent of belonging to a particular group, the theater, the staging of such expressions, can undoubtedly allow such transmission to lead to other places that Cultural world recreated and, along with this, contribute to generate more images of a humanity that, contrary to what the early theorists of globalization thought, becomes increasingly diverse. ${ }^{22-23}$

\section{Acknowledgements}

I thank Francisco Sanchez, actor and theater director for inviting me to participate in this project and encourage me to write these reflections and to Cesar Ancalaf, Mapuche poet, who helped me to understand a part of the rich cosmology of his people. Finally, I thank all the Mapuche families who shared with us in the course of the field research curricular synthesis.

\section{Conflicts of interest}

Author declares that there is no conflict of interest.

\section{References}

1. Victor T. Dramas, Fields and Metaphors: Symbolic Action in Human Society. Ithaca and London: Cornell University Press; 1974.

2. Ernesto B. Treaty of theatrical anthropology. The paper canoe. Mexico: Gazette; 1992.

3. Ernesto B, Nicola S. The secret art of the actor. Dictionary of theatrical anthropology. Mexico: Escenología; 1990.

4. Ángel AB. Ethnography. Qualitative methodology in socio-cultural research. Barcelona: Boixareu Universitaria; 1995.

5. Rosana G. Ethnography. Cambridge: Cambridge University Press; 2001 .

6. Hammesrsley M, Atkinson P. Ethnography. Research Methods. Barcelona: Ediciones Paidos; 1983.

7. Edward T. "The science of culture". In: Kahn J, editor. The concept of culture: fundamental texts. Barcelona: Anagrama; 1974. p. 29-46.

8. Adam K. Culture, the version of anthropologists. 1999.

9. Claude LS. The Elementary Structures of Kinship. Buenos Aires: Paidós; 1969.

10. Marvin H. A history of theories of culture. The development of anthropological theory. Mexico: Siglo XXI; 1979.

11. Victor T. The jungle of two symbols. Mexico: Siglo XXI; 1980.

12. Pierre B, Michael I. Akal Dictionary of Ethnology and Anthropology. Cambridge: Cambridge University Press. 1997. 
13. Claude LS. The myth and the story. In: Jáuregui J, Gourio Y, editors. Words returned. Mexico: SEP, INAH, IFAL, CEMCA, 1986.

14. Mircea E. The myth of the eternal return. Madrid: Alianza; 1972.

15. Emile D. The elemental forms of the religious life. Mexico: Fondo de Cultura Económica; 1912.

16. Curaqueo D. Mapuche religious beliefs. Critical review of current interpretations. Revista Chilena de Antropología. 1989;8:27-33.

17. Pedro M. The Araucanian imagination. Santiago: LOM; 1997.

18. José D. The Myth of "Treng-Treng Kaikai" of the Mapuche People. Universidad Católica de Temuco; 2007.
19. César A. Manual of culture and language Mapuche. 2006.

20. Eric W. Europe and the people without history. Buenos Aires: Fondo de Cultura Económica; 1982.

21. Louis F. The Mapuche. Its social structure. Mexico: Inter-American Indian Institute; 1969.

22. Norman L. "Globalization and localization: New challenges for rural research". In: Grammont H, Tejera HC, editors. The Mexican rural society facing the new millennium. Mexico: INAH/UNAM/UAM/Plaza and Valdés; 1996.

23. Victor T. From Ritual to Theater: The Human Seriousness of Play. New York: Performing Arts Journal Publications; 1982. 